\title{
Analyzing Individual, Institutional, and Regional Contributions to E-tourism: The Case of ENTER Proceedings (1996-2021)
}

\author{
Suki Siuki Tam ${ }^{1}$, Huiyue $\mathrm{Ye}^{2}$ (D), Rob Law ${ }^{2,3}$ (D), \\ and Lawrence Hoc Nang Fong ${ }^{2(凶)}$ (D) \\ ${ }^{1}$ School of Hotel and Tourism Management, The Hong Kong Polytechnic \\ University, Hong Kong S.A.R., China \\ 2 Department of Integrated Resort and Tourism Management, \\ Faculty of Business Administration, University of Macau, Macau SAR, China \\ \{roblaw, lawrencefong $\} @ u m . e d u . m o$ \\ 3 Asia-Pacific Academy of Economics and Management, \\ Department of Integrated Resort and Tourism Management, \\ Faculty of Business Administration, University of Macau, Macau SAR, China
}

\begin{abstract}
ENTER conference is an annual international event organized by the International Federation for Information Technology and Travel and Tourism (IFITT). Since 1994, this conference has been providing a platform for academics, industry practitioners, governments, and other organizations to share their research about information and communication technologies application in tourism. In the conference, the IFITT community mainly focuses on three streams, namely, research, destinations, and industry. The studies presented at the ENTER conference were published in the content of ENTER proceedings. The current study analyzes the proceedings published from 1996 to 2021 (i.e., 26 issues) to understand the individual, institutional, and regional contributions to e-tourism within these 26 years.
\end{abstract}

Keywords: ENTER conference - IT - Tourism - Authors - Institutes · Regions · Contribution

\section{Introduction}

Conventional industries have been changed by the evolution of information and communication technologies (ICT), in terms of product development and consumption. Therefore, new business models are needed in the tourism industry [1]. Technologies are also transforming tourism management and marketing strategies. To obtain a complete view of the influence of technological advances on the tourism industry, continuous and innovative tourism technology research effort is needed [2]. Before the 1990s, very limited contributions to tourism and technology were published. Since 1994, the ENTER conference annually offers a forum for academics, practitioners, governments, and organizations to share their latest research findings of information and technology in the tourism industry $[3,4]$. As the leading international academic conference on tourism and technology, ENTER provides a platform for professional

(C) The Author(s) 2022 
researchers in publishing quality research articles. Aiming to provide a general view of authors' contributions to this research realm in ENTER conferences, this study reviewed the accessible 26 issues of conference proceedings from 1996 to 2021 . A total of 1,217 research papers were incorporated into the analysis, with 1,697 individual authors who were affiliated to different regions/countries of continents. Individual, institutional, and regional contributions to information and technology in the tourism industry in the recent 26 years are presented in this study.

\section{Literature Review}

\subsection{Research Productivity Analysis}

Van Over and Nelson [5] indicated that identifying and evaluating major research contributions are periodically necessary to record the historical evolution and provide a sense for future study. The tourism and hospitality academic community devoted the greatest efforts to conducting research [6]. Although the importance of research is recognized, no common ways are adopted to evaluate research performance in hospitality and tourism research [7]. Harris [8] stated that four different methods can be used to measure research performance, namely, impact, quality, importance, and quantity. Impact represents the influence level of a related article. Importance and quality are evaluated by reviews and value judgments so that the results are subjective particularly when the academic research output is evaluated in different periods of time. Then, quantity is the most pragmatic way to measure research productivity, that is, by counting the number of publications issued. In the field of tourism and hospitality, authorship and institution analyses are frequently used to assess research performance by counting the number of publications [6, 7, 9-11]. Prior tourism review research seldom evaluated productivity on specific areas, such as information technology (IT) in tourism [12].

\subsection{IT in Tourism Research}

Since the 1980s, ICT has started influencing the tourism industry in terms of business practices, marketing strategies, and industry structure [13]. More importantly, the implementation of technologies is an effective strategy to enhance tourist destination competitiveness [14]. By serving as an effective liaison among heterogeneous stakeholders, ICT promotes the information exchange of the tourism ecosystem and therefore fosters globalization [15]. With the evolution of technologies, such as 5G, Internet of Things, blockchain, and augmented reality, tourism is transforming from eTourism to smart tourism and then to the forthcoming ambient intelligence tourism [14]. The successful technology adoption in the tourism industry not only enhances the tourist experience but also promotes the sustainable development of the destination by assisting better resource management [16]. This irreversible development trend has a disruptive influence on the tourism industry and therefore has attracted significant attention from scholars, practitioners, and governments [4].

The literature reflects that very limited studies related to tourism and technology were published before 1990. In 1994, the annual ENTER conference gathered researchers who 
share multiple interests in tourism and IT development to exchange their research findings. This group of researchers constituted a research community called the International Federation of Information Technology for Travel and Tourism (IFITT) [3, 4]. Since then, a proliferation of IT and tourism research is witnessed [17]. Key review studies can help academics keep pace with the state-of-the-art IT and tourism research [18]. For example, Buhalis and Law [4] reviewed the development progress of IT in tourism research in the past 20 years before 2008. In addition, Law, Qi, and Buhalis [19] summarized the tourism website evaluation research in the past 15 years (i.e., from 1996 to 2009). Leung, Law, van Hoof, and Buhalis [20] focused on emerging social media-relevant tourism research. Moreover, the recent decade witnessed several IT and tourism systematic reviews that analyzed the categorization of pertinent research themes, development trends, and coauthorship of key researchers [17-21]. Although several review papers provided an outline of the development of IT and tourism research, conference papers were usually excluded from the analyzed scope. Therefore, considering the limited understanding of research productivity and individual and institutional contributions to IT and tourism research, ENTER conference proceedings from 1996 to 2021 were analyzed to provide a wider view for academics, industry practitioners, and governments [12].

\section{Methodology}

In this study, the articles published in the Information and Communication Technologies in Tourism: Proceedings of the ENTER conferences (1996-2021) were examined. During this period, a total of 1,217 research papers were included in ENTER proceedings, comprising full- and short-length articles.

This study is regarded as an extension of the previous study [12] to update the trend of contribution in past decades. Publications in ENTER proceedings were analyzed by year to determine the trend of contribution in terms of region, individual author, and institute. In addition to the publication counting method adopted by previous research, this study used the same method advised by Sheldon [6] in analyzing authorship. To analyze the tourism research contributions, two measurements were calculated: instances and weighted instances. The former represents the number of articles an author contributed either partially or fully. The latter prorates the partial contribution of co-authors by using equal weight [6]. Although first authors may have contributed more than other authors, weighted instance assumes that each co-author's contribution to the research is equal.

\section{Findings and Discussions}

\subsection{Distribution of Papers by Year}

From 1996 to 2021, a total of 1,217 research papers were included in the ENTER conference proceedings, comprising full- and short-length papers. The average number of papers per year is 46.8. In the first 10 years from 1996 to 2005 , the number of articles gradually increased from 25 to 51 . Then, from 2007 to 2013, the number of 
papers dropped and fluctuated between 42 and 50. In 2014, a total of 65 research papers were published. The number of published articles reached its peak and then dropped significantly to the lowest point in 2020 (i.e., 25 papers). In 2021, the article number rebounded back to 55. Figure 1 shows the trend of publication within 26 years.

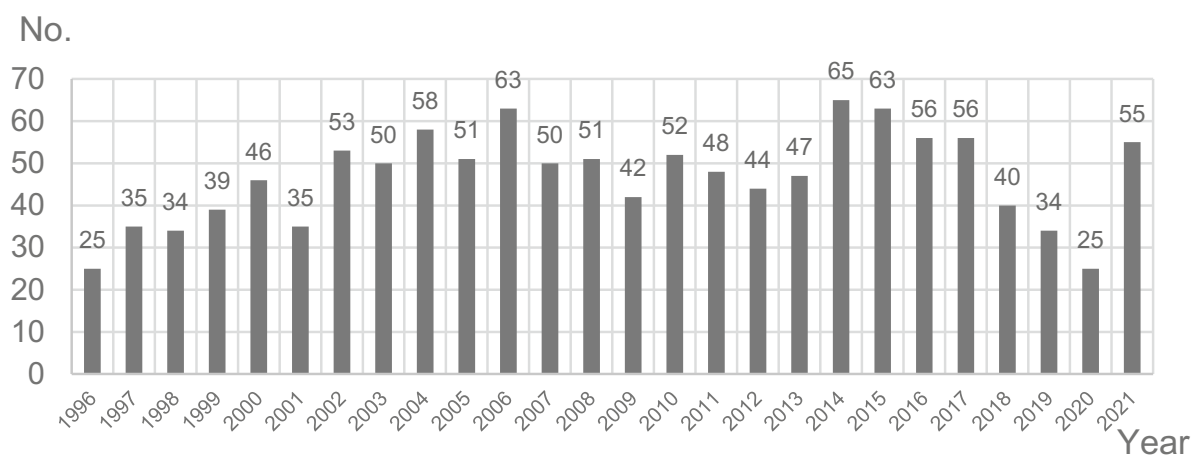

Fig. 1. Distribution of papers in 1996-2021

\subsection{Research Contributions by Continent/Country/Region}

As shown in Table 1, Europe is the most productive continent at the ENTER conference with a total of 2,257 (69.17\%) published papers in instances and 830.96 $(68.56 \%)$ papers in weighted instances. Liu, Zhong, Ip, and Leung (2011) found that, until 2010, America was the second-largest contributing region [12]. After a decade, however, Asia's contribution rapidly increased and became the second-largest contributing region with $433(13.27 \%)$ papers in instances and $146.93(12.12 \%)$ papers in weighted instances. America ranked third with $351(10.76 \%)$ papers in instances and $144.00(11.88 \%)$ papers in weighted instances. Oceania ranked fourth, with a total of 197 papers in instances and 77.78 papers in weighted instances and contributed $6.04 \%$ and $6.42 \%$ to the analyzed realm. Of all publications, Africa was the least productive continent providing $0.77 \%$ in instance and $1.02 \%$ in weighted instance.

The results of the top three productive countries are in line with the findings of 10 years ago [12]. Considering the cradle of ENTER conference, in the past 26 years, the majority of the authors were from Austria. They contributed to the conference by publishing a total of $497(15.23 \%)$ papers in instances and $173.94(14.35 \%)$ papers in weighted instances. The second-largest contributing country was the United Kingdom, with $378(11.58 \%)$ published papers in instances and $170.62(14.08 \%)$ papers in weighted instances. The United States was the third one with $313(9.59 \%)$ papers in instances and $130.35(10.75 \%)$ papers in weighted instances. Table 1 shows the details of contributions provided by other countries and their ranks. 
Table 1. Research contributions by geographic region

\begin{tabular}{|c|c|c|c|c|c|c|c|c|}
\hline \multirow[b]{2}{*}{$\begin{array}{l}\text { Continent/ } \\
\text { Country/ } \\
\text { Region }\end{array}$} & \multicolumn{4}{|c|}{ Instances } & \multicolumn{4}{|c|}{ Weighted Instances } \\
\hline & Number & $\begin{array}{l}\text { World } \\
\text { Rank }\end{array}$ & $\begin{array}{l}\text { Rank in } \\
\text { the } \\
\text { Continent }\end{array}$ & $\%$ & Number & $\begin{array}{l}\text { World } \\
\text { Rank }\end{array}$ & $\begin{array}{l}\text { Rank in the } \\
\text { Continent }\end{array}$ & $\%$ \\
\hline Europe & 2,257 & $\underline{1}$ & & $\underline{69.17 \%}$ & $\underline{830.96}$ & & & $68.56 \%$ \\
\hline Austria & 497 & 1 & 1 & & 173.94 & 1 & 1 & \\
\hline UK & 378 & 2 & 2 & & 170.62 & 2 & 2 & \\
\hline Switzerland & 287 & 4 & 3 & & 91.34 & 5 & 4 & \\
\hline Italy & 280 & 5 & 4 & & 95.43 & 4 & 3 & \\
\hline Spain & 274 & 6 & 5 & & 77.29 & 6 & 5 & \\
\hline Germany & 158 & 8 & 6 & & 59.03 & 8 & 6 & \\
\hline Finland & 71 & 12 & 7 & & 28.05 & 10 & 7 & \\
\hline $\begin{array}{l}\text { The } \\
\text { Netherlands }\end{array}$ & 56 & 13 & 8 & & 17.53 & 15 & 10 & \\
\hline Greece & 55 & 14 & 9 & & 25.12 & 11 & 8 & \\
\hline Sweden & 45 & 16 & 10 & & 15.24 & 18 & 12 & \\
\hline France & 37 & 17 & 11 & & 19.33 & 14 & 9 & \\
\hline Norway & 36 & 18 & 12 & & 16.83 & 16 & 11 & \\
\hline Estonia & 17 & 21 & 13 & & 5.00 & 26 & 16 & \\
\hline Denmark & 16 & 23 & 14 & & 10.08 & 21 & 13 & \\
\hline Portugal & 13 & 26 & 15 & & 5.50 & 25 & 15 & \\
\hline Belgium & 12 & 27 & 16 & & 6.92 & 23 & 14 & \\
\hline Ireland & 7 & 30 & 17 & & 2.87 & 31 & 18 & \\
\hline Croatia & 6 & 31 & 18 & & 4.00 & 28 & 17 & \\
\hline Yugoslavia & 4 & 33 & 19 & & 1.00 & 36 & 20 & \\
\hline Bulgaria & 2 & 37 & 20 & & 1.00 & 36 & 20 & \\
\hline Slovenia & 2 & 37 & 20 & & 2.00 & 33 & 19 & \\
\hline Cyprus & 1 & 42 & 22 & & 0.33 & 47 & 25 & \\
\hline Iceland & 1 & 42 & 22 & & 1.00 & 36 & 20 & \\
\hline Poland & 1 & 42 & 22 & & 1.00 & 36 & 20 & \\
\hline Serbia & 1 & 42 & 22 & & 0.50 & 44 & 24 & \\
\hline Asia & $\underline{433}$ & $\underline{2}$ & & $\underline{13.27 \%}$ & $\underline{146.93}$ & $\underline{2}$ & & $12.12 \%$ \\
\hline Hong Kong & 158 & 8 & 1 & & 58.05 & 9 & 1 & \\
\hline $\begin{array}{l}\text { South } \\
\text { Korea }\end{array}$ & 83 & 10 & 2 & & 23.63 & 13 & 3 & \\
\hline Japan & 75 & 11 & 3 & & 24.50 & 12 & 2 & \\
\hline $\begin{array}{l}\text { China } \\
\text { (Mainland) }\end{array}$ & 51 & 15 & 4 & & 15.75 & 17 & 4 & \\
\hline $\begin{array}{l}\text { United } \\
\text { Arab } \\
\text { Emirates }\end{array}$ & 14 & 24 & 5 & & 5.95 & 24 & 5 & \\
\hline Macao & 14 & 24 & 5 & & 5.00 & 26 & 6 & \\
\hline Malaysia & 12 & 27 & 7 & & 3.68 & 30 & 8 & \\
\hline Taiwan & 11 & 29 & 8 & & 4.00 & 28 & 7 & \\
\hline Turkey & 6 & 31 & 9 & & 1.53 & 35 & 11 & \\
\hline Israel & 4 & 33 & 10 & & 2.33 & 32 & 9 & \\
\hline Thailand & 4 & 33 & 10 & & 2.00 & 33 & 10 & \\
\hline Oman & 1 & 42 & 12 & & 0.50 & 44 & 12 & \\
\hline
\end{tabular}




$\begin{array}{lcccccccc}\text { America } & \underline{351} & \underline{3} & & \underline{10.76 \%} & \underline{144.00} & \underline{3} & & \underline{11.88 \%} \\ \text { USA } & 313 & 3 & 1 & & 130.35 & 3 & 1 & \\ \text { Canada } & 35 & 19 & 2 & & 12.90 & 19 & 2 & \\ \text { Brazil } & 2 & 37 & 3 & & 0.50 & 44 & 3 & \\ \text { Mexico } & 1 & 42 & 4 & & 0.25 & 48 & 4 & \\ \text { Oceania } & \underline{197} & \underline{4} & & \underline{6.04 \%} & \underline{77.78} & \underline{4} & & \underline{6.42 \%} \\ \text { Australia } & 170 & 7 & 1 & & 66.95 & 7 & 1 & \\ \text { New } & 27 & 20 & 2 & & 10.83 & 20 & 2 & \\ \text { Zealand } & \underline{25} & \underline{5} & & \underline{0.77 \%} & \underline{12.33} & \underline{5} & & \underline{1.02 \%} \\ \text { Africa } & 17 & 21 & 1 & & 8.67 & 22 & 1 & \\ \text { South } & 3 & 36 & 2 & & 1.00 & 36 & 2 & \\ \text { Africa } & 2 & 37 & 3 & & 1.00 & 36 & 2 & \\ \text { Nigeria } & 2 & 37 & 3 & & 0.67 & 43 & 5 & \\ \text { Egypt } & 1 & 42 & 5 & & 1.00 & 36 & 2 & \\ \text { Morocco } & & & & & & & & \\ \text { Namibia } & 17 & & & & & & & \\ \end{array}$

\subsection{Research Contributions by Individual Authors}

Authors' contributions to the ENTER conference from 1996 to 2021 are demonstrated in this section. In conformity with Liu, Zhong, Ip, and Leung [12], this study also adopted the classification suggested by Sheldon [6] and Jogaratnam et al. [10]. Therefore, three types of authors exist, namely, one-time, moderately contributing, and intensely contributing authors [6-10]. The one-time author refers to an author who only contributed one article. The moderately contributing author represents an author who contributed two to four times. Finally, the intensely contributing author represents an author who contributed five times or above. Table 2 shows the research contributions by these three types of individual authors.

From 1996 to 2021, a total of 1,697 individual authors participated in ENTER conferences. Most of the papers were contributed by 1,250 one-time authors $(73.66 \%)$. The number of moderately contributing author was $337(19.86 \%)$. In addition, a total of $110(6.48 \%)$ authors intensely contributed to this conference.

Table 2. Research contributions by individual authors

\begin{tabular}{l|l|l|l|l|l|l}
\hline Total number of authors & \multicolumn{2}{|l|}{$\begin{array}{l}\text { One-time } \\
\text { authors }\end{array}$} & \multicolumn{2}{l|l}{$\begin{array}{l}\text { Moderately } \\
\text { contributing } \\
\text { authors }\end{array}$} & \multicolumn{2}{l}{$\begin{array}{l}\text { Intensely } \\
\text { contributing } \\
\text { authors }\end{array}$} \\
\cline { 2 - 8 } & Number & $\%$ & Number & $\%$ & Number & $\%$ \\
\hline 1,697 & 1250 & 73.66 & 337 & 19.86 & 110 & 6.48 \\
\hline
\end{tabular}

Table 3 lists the top 30 intensely contributing authors. The top three contributors were Dimitrios Buhalis, Rob Law, and Daniel R Fesenmaier, with 57, 56, and 40 papers in instances among 26 issues. Apart from the number of papers, Table 3 also shows the first year of the contribution of each author to clearly reflect their seniority in the ENTER conference (Table 4). 
Table 3. Top 30 intensely contributing authors

\begin{tabular}{|c|c|c|c|c|c|}
\hline \multirow[t]{2}{*}{ Author } & \multirow{2}{*}{$\begin{array}{l}\text { First year of } \\
\text { contribution }\end{array}$} & \multicolumn{2}{|l|}{ Instances } & \multicolumn{2}{|c|}{ Weighted instances } \\
\hline & & $\begin{array}{l}\text { Number of } \\
\text { papers }\end{array}$ & Rank & $\begin{array}{l}\text { Number of } \\
\text { papers }\end{array}$ & Rank \\
\hline Dimitrios Buhalis & 1996 & 57 & 1 & 24.33 & 1 \\
\hline Rob Law & 2000 & 56 & 2 & 20.72 & 2 \\
\hline $\begin{array}{l}\text { Daniel R } \\
\text { Fesenmaier }\end{array}$ & 1996 & 40 & 3 & 17.15 & 3 \\
\hline Ulrike Gretzel & 2000 & 35 & 4 & 14.12 & 6 \\
\hline Lorenzo Cantoni & 2009 & 30 & 5 & 10.40 & 8 \\
\hline Wolfram Höpken & 1999 & 26 & 6 & 8.15 & 12 \\
\hline Matthias Fuchs & 2005 & 26 & 6 & 6.70 & 17 \\
\hline Jamie Murphy & 2003 & 25 & 8 & 7.07 & 16 \\
\hline Roland Schegg & 2002 & 24 & 9 & 7.57 & 14 \\
\hline $\begin{array}{l}\text { Aurkene Azua- } \\
\text { Sorzabal }\end{array}$ & 2005 & 22 & 10 & 5.55 & 21 \\
\hline Iis P Tussyadiah & 2007 & 21 & 11 & 11.75 & 7 \\
\hline Francesco Ricci & 2001 & 21 & 11 & 7.52 & 15 \\
\hline Peter O'Connor & 1998 & 19 & 13 & 14.83 & 5 \\
\hline Andrew J Frew & 1997 & 19 & 13 & 8.92 & 10 \\
\hline Hannes Werthner & 1996 & 19 & 13 & 8.26 & 11 \\
\hline Zheng Xiang & 2004 & 19 & 13 & 7.78 & 13 \\
\hline Roman Egger & 2007 & 19 & 13 & 6.38 & 18 \\
\hline $\begin{array}{l}\text { María Teresa } \\
\text { Linaza }\end{array}$ & 2005 & 19 & 13 & 5.24 & 23 \\
\hline Marianna Sigala & 2000 & 19 & 13 & 15.00 & 4 \\
\hline $\begin{array}{l}\text { Miriam } \\
\text { Scaglione }\end{array}$ & 2004 & 18 & 20 & 5.78 & 19 \\
\hline $\begin{array}{l}\text { Alessandro } \\
\text { Inversini }\end{array}$ & 2009 & 16 & 21 & 5.12 & 24 \\
\hline Elena Marchiori & 2009 & 16 & 21 & 4.90 & 26 \\
\hline Namho Chung & 2013 & 15 & 23 & 4.25 & 29 \\
\hline Rodolfo Baggio & 2003 & 14 & 24 & 5.75 & 20 \\
\hline Chulmo Koo & 2013 & 14 & 24 & 3.62 & 30 \\
\hline Rosanna Leung & 2006 & 13 & 26 & 4.67 & 27 \\
\hline Markus Zanker & 2006 & 13 & 26 & 3.41 & 31 \\
\hline Karl Wöber & 1994 & 13 & 26 & 9.78 & 9 \\
\hline Astrid Dickinger & 2006 & 12 & 29 & 5.37 & 22 \\
\hline Timothy Jung & 2000 & 12 & 29 & 5.00 & 25 \\
\hline
\end{tabular}




\subsection{Research Contributions by Institutes}

Table 4. Research contributions by the top 10 research institutes

\begin{tabular}{l|l|l|l|l|l}
\hline Institute (Country/Region) & $\begin{array}{l}\text { First Year of } \\
\text { contribution }\end{array}$ & Instances & Rank & $\begin{array}{l}\text { Weighted } \\
\text { instances }\end{array}$ & Rank \\
\hline $\begin{array}{l}\text { The Hong Kong Polytechnic } \\
\text { University (HK) }\end{array}$ & 2000 & 147 & 1 & 50.15 & 1 \\
\hline University of Surrey (UK) & 1996 & 112 & 2 & 43.75 & 2 \\
\hline $\begin{array}{l}\text { Bournemouth University } \\
\text { (UK) }\end{array}$ & 2008 & 78 & 3 & 30.92 & 3 \\
\hline $\begin{array}{l}\text { Kyung Hee University } \\
\text { (South Korea) }\end{array}$ & 2013 & 68 & 4 & 18.73 & 5 \\
\hline $\begin{array}{l}\text { Università della Svizzera } \\
\text { italiana (Switzerland) }\end{array}$ & 2010 & 60 & 5 & 20.57 & 4 \\
\hline \begin{tabular}{l} 
University of Trento (Italy) \\
\hline CIC tour GUNE (Spain)
\end{tabular} & 2000 & 56 & 6 & 14.02 & 9 \\
\hline $\begin{array}{l}\text { MODUL University Vienna } \\
\text { (Austria) }\end{array}$ & 2008 & 46 & 8 & 18.28 & 7 \\
\hline $\begin{array}{l}\text { Salzburg University of } \\
\text { Applied Science (Austria) }\end{array}$ & 2007 & 44 & 9 & 11.22 & 11 \\
\hline $\begin{array}{l}\text { University of Illinois (USA) } \\
\begin{array}{l}\text { Temple University (USA) } \\
\hline\end{array}\end{array}$ & 1996 & 44 & 9 & 18.70 & 6 \\
\hline
\end{tabular}

This study recognized that the trend of publications on IT and Tourism changed in recent decades. From 1994 to 1999, the United Kingdom made the largest research contribution in the ENTER conference, which was followed by Austria, Germany, the USA, and the Netherlands [22]. However, the ranking was slightly different from that in the past because of the engagement of industry practitioners from Austria and Italy. From 1994 to 2010, Austria became the most productive country, followed by the UK, the USA, Italy, and Germany. The findings of this study pointed out that in the past decade, the top three contributing countries were the same. Moreover, the research productivity of Switzerland and Spain has increased. In general, the contribution of Asia was increasing year by year, particularly in the past 10 years. Research contributions from The Hong Kong Polytechnic University (HK) and Kyung Hee University (South Korea) surged.

\section{Conclusions}

\subsection{Summary of the Study}

IT plays an important role in the tourism and hospitality industry. To gain additional knowledge about current situations and to predict future trends, continuous academic research in IT applications on tourism is essential. This study has examined the 
individual, regional, and institutional contributions to IT and tourism research by analyzing the articles published in ENTER proceedings from 1996 to 2021. A total of 1,217 research papers were contributed by 1,697 individual authors in the past 26 years. The total number of research contributions increased year by year. Regarding the regional contributions, Europe was the most productive continent, followed by Asia, America, Australia, and Africa. Specifically, Austria had the largest research contribution by issuing 497 articles in instances. As for institutional contribution, the Hong Kong Polytechnic University (HK) was the most prolific institute, with a total of 147 research articles when counting in instances, followed by the University of Surrey (UK) and the Bournemouth University (UK). Regarding individual contributions, the top three authors were Dimitrios Buhalis, Rob Law, and Daniel Fesenmaier, and the years they started contributing to ENTER conferences varied (since 1996, 2000, and 1996 respectively).

\subsection{Implications}

The development of IT promotes the evolution of the tourism industry, which has disruptive effects on tourism management, marketing, and destination competitiveness [14]. This study aims to provide insights for academics, practitioners, and government officials to deeply understand the trend of productivity on IT and tourism research. The findings of this study updated the research performance of individuals and institutes. The increasing number of published articles may motivate practitioners to pay additional attention to the importance of IT in the tourism industry.

In terms of theoretical implications, this study extends the IT and tourism research by conducting a productivity analysis. Publications in the ENTER conference proceedings from 1996 to 2021 were selected as the research scope, which bridges the previous research gap. The results quantified the research contribution of individuals, institutions, and regions.

Several practical implications are provided. The ranking of individual and institutional contributions may be regarded as a reference for organizations and educational institutions, particularly for the recruitment of researchers. Research institutes may determine remuneration packages by reviewing candidates' research contributions in these fields. We believe that this research finding may help recruit high-quality candidates.

Apart from recruitment purposes, this study also reflects the institutional research contribution in the IT and tourism industry. For those who are planning for their higher education or career path, the findings may help them select professional and highquality institutes.

Based on the findings, the ENTER conference has recently gained momentum in internationalization. In the past decades, most participants came from Europe and North America. However, the findings show that the research contribution of Asia has largely increased in the recent decade. The research contribution not limiting to specific regions made this conference more globalized. Advanced technology development in Asia, particularly in Mainland China, is recognized by the world, for example, the 5G development is a popular topic nowadays. We believe that this technology transformation might create a significant influence on the tourism industry and provide a new 
direction for academic research. In addition, the ENTER conference 2022 will take place in Mainland China, indicating the growing significance of Asia, and the growing number of Asian participants would be promising.

Finally, this study attempts to appeal attention to IT and the tourism industry. Academics are encouraged to initiate additional international collaborations and contribute to knowledge development. In addition, to increase the impact of research, collaborations among academics, practitioners, and governments are recommended.

\subsection{Limitations and Future Studies}

This study has some limitations. First, from 1994 to 2021, a total of 28 ENTER proceedings were published. However, this study only analyzed 26 issues (1996-2021) of ENTER conference proceedings because of the inaccessibility of proceedings in 1994 and 1995. In addition, some promising and productive young scholars that started to participate in the ENTER conference in recent years are not noted in this study. Thus, in future studies, researchers are suggested to complete and update the result of the findings. Second, in terms of the analyzed content, although this study provides the first year of contribution as a reference, the analysis did not delve into this part. Readers might take this component into account when evaluating author's contribution. Moreover, the popularity such as Google Scholar's h-index of some prolific authors can be provided for comparison in a future study. Third, in comparison to the institutional contribution, the findings of individual productivity were more accurate to reflect the fact. The reason is that job switching of researchers can influence the productivity of institutes, particularly for authors with a high level of contribution. Meanwhile, there may be some missing articles because of the changes of the official name of institutions. For example, Università della Svizzera italiana (Switzerland) is also called University of Lugano. Therefore, changes of author's affiliation and institution names should be considered in future research. Finally, the results only reveal the contribution of authors who published articles in ENTER conference proceedings. Articles published in other pertinent journals, conferences, and books are recommended to be incorporated into analysis for generating a comprehensive result.

Acknowledgement. This project was partly supported by a research grant funded by the University of Macau (Ref.: CPG2021-00036-APAEM).

\section{References}

1. Bilotta E, Bertacchini F, Gabriele L, Giglio S, Pantano PS, Romita T (2020) Industry 4.0 technologies in tourism education: nurturing students to think with technology. J Hosp Leis Sports Tour Educ 100275. https://doi.org/10.1016/j.jhlste.2020.100275

2. Sigala M (2018) New technologies in tourism: from multi-disciplinary to anti-disciplinary advances and trajectories. Tour Manag. Perspect. 25:151-155. https://doi.org/10.1016/j.tmp. 2017.12.003 
3. Law R (2002) Across the C's: commerce, Convergence, Communications and Change ENTER 2001 held in Montréal, Canada in April 2001. J Travel Tour Mark 12:97-101. https://doi.org/10.1300/J073v12n01_06

4. Buhalis D, Law R (2008) Progress in information technology and tourism management: 20 years on and 10 years after the Internet-The state of eTourism research. Tour Manag 29:609-623. https://doi.org/10.1016/j.tourman.2008.01.005

5. Van Over L, Nelson R (1986) Research in management information systems, 1980-1985: a profile of leading journals, articles, and authors. In: the 18th annual meeting of the decision sciences institute, Honolulu, HI

6. Sheldon PJ (1991) An authorship analysis of tourism research. Ann Tour Res 18:473-484. https://doi.org/10.1016/0160-7383(91)90053-E

7. Law R, Chon K (2007) Evaluating research performance in tourism and hospitality: the perspective of university program heads. Tour Manag 28:1203-1211. https://doi.org/10. 1016/j.tourman.2006.09.022

8. Harris GT (1990) Research output in Australian university economics departments: an update for 1984-88. Aust Econ Pap 29:249-259. https://doi.org/10.1111/j.1467-8454.1990. tb00520.x

9. Malhotra MK, Kher HV (1996) Institutional research productivity in production and operations management. J Oper Manag 14:55-77. https://doi.org/10.1016/0272-6963(95) $00037-2$

10. Jogaratnam G, McCleary KW, Mena MM, Yoo JJE (2005) An analysis of hospitality and tourism research: institutional contributions. J. Hosp. Tour Res. 29:356-371. https://doi.org/ $10.1177 / 1096348005276929$

11. Weaver P (1990) Academic contributors to four major hospitality journals revisited. J Hosp Tour Educ 2:30-32

12. Liu W, Zhong L, Ip C, Leung D (2011) An analysis of research on tourism information technology: the case of ENTER proceedings. In: Law R, Fuchs M, Ricci F (eds) Information and communication technologies in tourism 2011. Springer, Vienna, pp 293-304. https://doi. org/10.1007/978-3-7091-0503-0_24

13. Porter ME (2001) Strategy and the Internet. Harv Bus Rev 79:62-78

14. Buhalis D (2019) Technology in tourism-from information communication technologies to eTourism and smart tourism towards ambient intelligence tourism: a perspective article. Tour Rev 75:267-272. https://doi.org/10.1108/TR-06-2019-0258

15. Buhalis D (1998) Strategic use of information technologies in the tourism industry. Tour Manag 19:409-421. https://doi.org/10.1016/S0261-5177(98)00038-7

16. Mayer-Schönberger V, Cukier K (2013) Big data: a revolution that will transform how we live, work, and think Houghton Mifflin Harcourt, Boston

17. Mehraliyev F, Chan ICC, Choi Y, Koseoglu MA, Law R (2020) A state-of-the-art review of smart tourism research. J Travel Tour Mark 37:78-91. https://doi.org/10.1080/10548408. 2020.1712309

18. Tranfield D, Denyer D, Smart P (2003) Towards a methodology for developing evidenceinformed management knowledge by means of systematic review. Br J Manag 14:207-222. https://doi.org/10.1111/1467-8551.00375

19. Law R, Qi S, Buhalis D (2010) Progress in tourism management: a review of website evaluation in tourism research. Tour Manag 31:297-313. https://doi.org/10.1016/j.tourman. 2009.11.007 
20. Leung D, Law R, van Hoof H, Buhalis D (2013) Social media in tourism and hospitality: a literature review. J Travel Tour Mark 30:3-22. https://doi.org/10.1080/10548408.2013. 750919

21. Ye BH, Ye H, Law R (2020) Systematic review of smart tourism research. Sustainability 12:3401. https://doi.org/10.3390/su12083401

22. Frew AJ (2000) A critical analysis of tourism information technology research. In: Fesenmaier DR, Klein S, Buhalis D (eds) Information and communication technologies in tourism 2000. Springer, Vienna, pp 39-52. https://doi.org/10.1007/978-3-7091-6291-0_4

Open Access This chapter is licensed under the terms of the Creative Commons Attribution 4.0 International License (http://creativecommons.org/licenses/by/4.0/), which permits use, sharing, adaptation, distribution and reproduction in any medium or format, as long as you give appropriate credit to the original author(s) and the source, provide a link to the Creative Commons license and indicate if changes were made.

The images or other third party material in this chapter are included in the chapter's Creative Commons license, unless indicated otherwise in a credit line to the material. If material is not included in the chapter's Creative Commons license and your intended use is not permitted by statutory regulation or exceeds the permitted use, you will need to obtain permission directly from the copyright holder. 